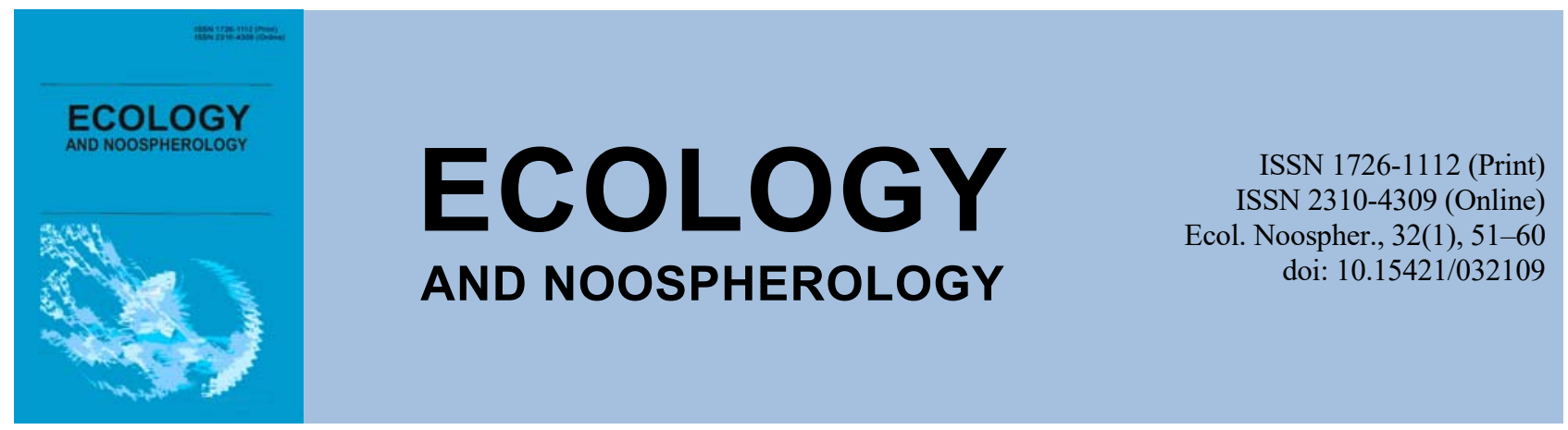

\title{
Influence of anthropogenic factors on the fauna of diplopods in the steppe zone of Ukraine
}

\author{
V. M. Kozak \\ Oles Honchar Dnipro National University, Dnipro, Ukraine
}

Article info

Received 02.03.2021

Received in revised form

15.03.2021

Accepted 28.03.2021

Oles Honchar Dnipro

National University,

Gagarin Ave., 72, Dnipro,

49010, Ukraine.

Tel.: 38097-340-15-89

E-mail:kozakv@i.ua

\begin{abstract}
Kozak, V. M. (2021). Influence of anthropogenic factors on the fauna of diplopods in the steppe zone of Ukraine. Ecology and Noospherology, 32(1), 51-60. doi:10.15421/032109
\end{abstract}

Various industries that constantly pollute the environment with their waste are quite well developed in the steppe zone of Ukraine. That in turn affects living organisms. The analysis of literature sources allowed to determine the factors influencing the diplopods fauna of the Steppe. Parasites, herbicides, fungicides, insecticides, heavy metals and other pollutants adversely affect invertebrates. Pesticides (glyphosate, imidacloprid, dimethoate, pirimiphos-methyl, propargite, cypermethrin, tebuconazole, chlorpyrifos, mefenoxam, mancozeb, sulfur, propiconazole, cyprodinil) are toxic to diplopods. They can affect lifetime, fertility, abundance, coordination of movements, feeding rates, change body weight and even in high concentrations cause the death of these animals. Sulfur, pirimiphos-methyl, propiconazole, imidacloprid, dimethoate and cypermethrin are the most toxic of all these pesticides. They cause the highest mortality. Heavy metals accumulate in the bodies of saprophages, reduce their abundance, affect body weight, cause a change in the intensity of eating food by diplopods. Nickel, lead, cadmium, zinc, cuprum and ferrum are toxic to millipedes. High concentrations of cadmium cause $100 \%$ mortality of Megaphyllum kievense (Lohmander, 1928). The development of urbanization causes a decrease in the abundance of saprophages. The species composition and number of individuals of some taxonomic groups of millipedes are reduced in reclamation areas. The nematodes Steinernema carpocapsae (Weiser, 1955) and Heterorhabditis heliothidis (Khan, Brooks \& Hirschmann, 1976) slow down the protective reactions of the body of Oxidus gracilis (C. L. Koch, 1847). The high intensity of diplopod infection with gregarines slows down the feeding process of Rossiulus kessleri (Lohmander, 1927). Lighting, soil humidity and the number of ants also affect the abundance of diplopods in natural forests and forest plantations of the steppe zone. Thus the diplopods are influenced by many environmental factors that can reduce their abundance in agrocenoses, forested and reclamation areas of the steppe zone of Ukraine.

Keywords: saprophages; Diplopoda; Julidae; litter invertebrates; heavy metals; pesticides; ecosystem pollution

\section{Вплив антропогенних чинників на фауну диплопод степової зони України}

\author{
В. М. Козак
}

Дніпровський національний університет імені Олеся Гончара, Дніпро, Україна

На території степової зони України досить добре розвинені різні галузі виробництва, що постійно забруднюють довкілля своїми відходами, а це, у свою чергу, впливає на живі організми. Аналіз літературних джерел дозволив визначити фактори, що діють на фауну диплопод Степу. Негативно впливають на організми безхребетних тварин паразити, гербіциди, фунгіциди, інсектициди, важкі метали та інші полютанти. Пестициди (гліфосат, імідаклоприд, диметоат, піриміфос-метил, пропаргіт, циперметрин, тебуконазол, хлорпірифос, мефеноксам, манкоцеб, сульфур, пропіконазол, ципродиніл) токсичні для диплопод. Вони здатні вплинути на тривалість життя, плодючість, чисельність, координацію рухів, темпи живлення, змінити масу тіла та навіть у високих концентраціях спричинити загибель цих тварин. 3 усіх перелічених пестицидів найтоксичніші - сульфур, піриміфос-метил, пропіконазол, імідаклоприд, диметоат і циперметрин. Вони спричиняють 
найвищу смертність. Важкі метали акумулюються в організмах сапрофагів, зменшують їх чисельність, впливають на масу тіла, спричиняють зміну інтенсивності споживання корму диплоподами. Нікель, свинець, кадмій, цинк, мідь і залізо токсичні для багатоніжок. У високих концентраціях кадмій викликає 100 \% смертність Megaphyllum kievense (Lohmander, 1928). Розвиток урбанізації сприяє зменшенню чисельності сапрофагів. На ділянках рекультивації видовий склад і кількість особин певних таксонів цих багатоніжок знижується. Нематоди Steinernema carpocapsae (Weiser, 1955) та Heterorhabditis heliothidis (Khan, Brooks \& Hirschmann, 1976) сповільнюють захисні реакції організму Oxidus gracilis (C. L. Koch, 1847). Висока інтенсивність зараження диплопод грегаринами сповільнює процес живлення Rossiulus kessleri (Lohmander, 1927). На кількість диплопод у природних лісах і лісонасадженнях степової зони впливають також освітленість, зволоження грунту та чисельність мурах. Таким чином, диплоподи в умовах степової зони України зазнають впливу багатьох факторів довкілля, здатних зменшувати їх чисельність в агроценозах, на лісовкритих територіях і на рекультивованих ділянках.

Ключові слова: сапрофаги; Diplopoda; Julidae; підстилкові безхребетні; важкі метали; пестициди; забруднення екосистем

\section{Вступ}

Щорічно 3 розвитком різних галузей виробництва у степовій зоні України зростає забруднення довкілля. Степова зона включає шість адміністративних областей цілком (Одеську, Миколаївську, Херсонську, Дніпропетровську, Запорізьку та Донецьку), а також фрагменти Кіровоградської, Луганської, Харківської та рівнинну частину AP Крим. Найтрансформованіша 3 найбільш розвиненою промисловістю - Дніпропетровська область. За даними Департаменту екології та природних ресурсів Дніпропетровської облдержадміністрації, у 2018 році на підприємствах області утворено 243,6 млн т відходів, із них найбільшу частку складають відходи чорних металів - 2263,7 тис. т. Постійно зростають обсяги внесення мінеральних добрив на сільськогосподарські угіддя, під урожай 2018 року внесено 1203,0 тис. т на 1058 тис. га. За даними управління фітосанітарної безпеки Головного управління Держпродспоживслужби в Дніпропетровській області, у 2018 р. аграрні підприємства області використали 2034,1 т різних препаративних форм пестицидів: інсектицидів - 265,9 т, гербіцидів - 1295,8, десикантів - 57,1, фунгіцидів - 254,8, протруйників 146,3 , родентицидів - 14,2 т. Основними забруднювачами довкілля залишаються підприємства металургійної, видобувної промисловості, виробники електроенергії та сільське господарство. Урбанізація зменшує площу природних місць існування диплопод. На порушених землях поблизу місць видобування корисних копалин порушується видовий склад грунтової мезофауни. Важкі метали та пестициди - одні 3 найважливіших чинників техногенного та агрогенного забруднення, оскільки ці хімікати здатні накопичуватися в різних компонентах екосистем (Pakhomov, Brygadyrenko, 2005; Moroz et al., 2011; Kozak, Brygadyrenko, 2018). У трофічній структурі грунтової мезофауни на території степової зони України переважають сапрофаги. Вони відіграють важливу роль у грунтоутворенні (Brygadyrenko, Komarov, 2008). Представники класу Diplopoda сприяють мінералізації рослинного опаду. На території Степу найчастіше зустрічаються такі види: Polydesmus inconstans Latzel, 1884, Schizothuranius dmitriewi (Timotheew, 1899), Brachyiulus jawlowskii Lohmander, 1928, Megaphyllum kievense (Lohmander, 1928), Megaphyllum rossicum (Timotheew, 1897), Megaphyllum sjaelandicum (Meinert, 1868), Rossiulus kessleri (Lohmander, 1927), Enantiulus nanus (Latzel, 1884) (Yakuba et al., 2003; Brygadyrenko, 2004; Kunah et al., 2008; Zhukov et al., 2017). Негативний вплив на організми диплопод чинять паразити, які оселяються в них. Зокрема, у кишечнику багатоніжок живуть нематоди (Poinar \& Thomas, 1985) та грегарини (Brygadyrenko \& Svyrydchenko, 2015), а на поверхні тіла - кліщі (Baker \& Seeman, 2008).

Пестициди, що застосовують в агроценозах, i важкі метали, які надходять від промислових джерел забруднення, разом із пилом і опадами потрапляють до лісосмуг і природних лісових екосистем (Shulman et al., 2017). Надходження до кишечника диплопод пестицидів i важких металів може спричиняти зміну метаболізму та, в кінцевому результаті, загибель цих безхребетних тварин. Урбанізовані території та ділянки рекультивації - об'єкти для комплексного дослідження факторів (забруднення, фрагментації популяцій, рекреації, проникнення адвентивних видів флори та фауни, вібрації від промислових виробництв і транспорту, ущільнення грунту тощо), які здатні по-різному впливати на організми диплопод.

Мета цієї статті - проаналізувати сучасні наукові джерела про вплив антропогенних чинників на фауну диплопод степової зони України.

\section{Поширення диплопод у природних умовах}

Диплоподи степової зони України зустрічаються у природних лісах і лісових насадженнях, навколоводних лучних екосистемах. Із сапрофагів у лісосмугах степової зони домінують диплоподи, ізоподи та дощові черв'яки (Brygadyrenko, 2006). Максимальна чисельність сапрофагів характерна для деревостанів Robinia pseudoacacia L., Fraxinus excelsior L. та Betula pubescens Ehrh. (Brygadyrenko, 2015b). У лабораторних умовах із листя 16 запропонованих видів дерев R. kessleri максимально споживали корм: Acer negundo L. (0,75 мг/мг маси тіла на добу), Quercus robur L. (0,50), Malus domestica Borkh. $(0,36)$ та Cerasus vulgaris L. $(0,35)$. Для 12 інших видів дерев споживання опаду не перевищувало 0,11 мг/мг маси тіла на добу (Svyrydchenko, Brygadyrenko, 2014). Таким чином, певні види диплопод вибірково споживають листя різних видів дерев, а отже, видовий склад лісових насаджень, створених людиною, визначає чисельність цієї групи сапрофагів (Pokhylenko et al., 2019).

У лісових екосистемах Південної України середня чисельність та кількість видів безхребетних у підстилці зменшується зі збільшенням зволоженості грунтів (Brygadyrenko, 2006, 2014). Важливий фактор існування диплопод у широколистяних і соснових лісах степової зони України - ступінь зволоження грунту. Чисельність грунтових безхребетних у соснових лісах уп'ятеро нижча, ніж у листяних лісах за однакового рівня зволоження. Під час зростання ступеня зволоження від мезоксерофільних до мезогігрофільних умов збільшується відносна кількість сапрофагів. у соснових лісах кількість особин безхребетних розміром понад 20 мм зменшується у більшості градацій зволоження (Brygadyrenko, 2014). Грунтових безхребетних можна використовувати як індикаторів градацій зволоження грунтів у лісах (Brygadyrenko, 2006). На чисельність диплопод в екосистемах Степу впливає наявність мурах. Зі збільшенням їхньої чисельності кількість сапофагів та фітофагів у підстилці полезахисної смуги зменшується (Faly, Brygadyrenko, 2014).

Важливу роль у поширенні диплопод широколистяних лісових екосистем відіграє фактор освітлення підстилки зімкненість крон дерев. У степовій зоні України відносна чисельність сапрофагів мінімальна в лісових екосистемах iз розрідженим наметом, а в лісах із більш зімкненим деревостаном вона має тенденцію до зростання (Brygadyrenko, 2015a). У підстилці соснових лісів із найменшою щільністю деревних наметів (30-40 \%) 
домінують Julidae (середній відсоток домінування за чисельністю - 31 \%). У лісах, представлених Рinus sylvestris L., зі збільшенням зімкненості деревного намету кількість таксонів Diplopoda зменшується. У хвойних лісах відносна чисельність сапрофагів (22 \%) нижча, ніж у листяних лісах (40%) (Brygadyrenko, 2016b). Для грунтових тварин підстилка відіграє важливу роль. Вона виступає i як джерело живлення, і як місце існування мезофауни. За потужності підстилки понад 40 мм на лісовкритих територіях степової зони України сумарна чисельність підстилкових безхребетних зростає (Brygadyrenko, 2016a).

\section{Вилив хімічних речовин на диплопод}

Починаючи 3 середини XX століття забруднення довкілля хімічними полютантами стає однією 3 пріоритетних загроз для живих організмів (Pakhomov, Brygadyrenko, 2005). Економічний розвиток і технічний прогрес спричиняють зміни у природних екосистемах степової зони. Із розвитком промисловості, збільшенням кількості транспорту, мережі автозаправок збільшується ризик зростання концентрації важких металів у довкіллі. Живі організми постійно відчувають на собі дію техногенних факторів, що негативно позначаються на їх існуванні. Так, Kunah (2005) свідчить, що концентрації 2 i 5 ГДК нікелю (46 і 115 мкг/г) та свинцю (40 і 100 мкг/г) зменшують чисельність Enchytraeidae spp. та збільшують відносну чисельність Sch. dmitriewi, Eisenia nordenskioldi (Eisen, 1879) та Allolobophora rosea Savigny, 1826. У представників класу Diplopoda, які проживають поблизу місць відкритого складування марганцевої руди на території Грушевського гірничо-збагачувального комбінату, кадмій і плюмбум накопичуються у незначній кількості порівняно 3 високим умістом таких мікроелементів, як $\mathrm{Fe}, \mathrm{Mn}, \mathrm{Cu}, \mathrm{Zn}$ i Ni (Kulbachko, Gasso, 2008). У сапрофагів виявлено найвищий індекс біологічного накопичення міді, марганцю та заліза. Порівняно 3 фітофагами та зоофагами сапрофаги акумулюють кадмій у найбільшій кількості, але індекс біологічного накопичення відносно кадмію у них найнижчий, а відносно свинцю цей індекс досить високий (Kulbachko, Gasso, 2008).

У лабораторних умовах сульфат цинку $\left(\mathrm{ZnSO}_{4} * 7 \mathrm{H}_{2} \mathrm{O}\right)$ токсичний для диплопод. Ця речовина акумулюється в організмі R. kessleri. Під час живлення багатоніжок кормом (листя Acer campestre L. чи Robinia pseudoacacia L.), зволоженим розчинами сульфату цинку $(0,006,0,03$ та 0,15 г/л), Pokhylenko et al. (2019) виявили в 1,5 разу менший уміст цинку в екскрементах R. kessleri, ніж у самій диплоподі. Концентрація цієї речовини в листяному опаді впливає на вміст цинку в сапрофагах та їх екскрементах (Pokhylenko et al., 2019). Солі заліза чинять певну дію на організм M. kievense. Під час живлення кормом із різним умістом заліза виявлено зміну маси тіла двопарноногих багатоніжок (Brygadyrenko, Ivanyshin, 2014). Кадмій та свинець $(0,3,3,30,300,3000$ і 30000 мг/кг підстилки) токсичні для організмів M. kievense. Це проявляється у збільшенні маси тіла та інтенсифікації мікробіологічного розкладання лісової підстилки. Максимальна концентрація кадмію спричиняє 100\%-ву загибель багатоніжок (Kozak, Brygadyrenko, 2018).

Вплив важких металів на комах досить добре досліджений (Shulman et al., 2017). Так, нітрати кадмію та свинцю у різних концентраціях $\left(10^{-2}-10^{-9} \mathrm{M}\right)$ впливають на розвиток личинок, лялечок та імаго Calliphora vicina Robineau-Desvoidy, 1830 (Diptera, Calliphoridae). Під час додавання в корм іонів свинцю встановлено прискорення розвитку личинок і збільшення маси пупаріїв, а додавання в корм іонів кадмію зменшує масу пупаріїв. Вплив цих важких металів спричиняе зниження рухової активності личинок мух на всіх стадіях розвитку, затримання формування пупаріїв та виникнення вад розвитку імаго
C. vicina порівняно 3 контрольною групою (Shulman et al., 2017). Солі міді негативно впливають на диплопод. Під час живлення $M$. kievense кормом, забрудненим найвищою концентрацією цього елементу $\left(10^{-1}\right.$ мг міді/г підстилки) Brygadyrenko, Ivanyshyn (2015), у лабораторних умовах протягом тридцяти діб виявили зниження у багатоніжок живильної та рухової активності (до 30,2 \% порівняно 3 контролем).

\section{Дія гербіцидів на багатоніжок}

Гліфосат - найпоширеніший гербіцид у світі, особливо в країнах, де сільське господарство займає провідну роль (Gangadhar et al., 2020). Найвідомішим препаратом iз умістом гліфосату для боротьби 3 однорічними та багаторічними рудеральними рослинами $€$ Roundup, запатентований компанією Monsanto в 1970 році. Ця компанія стверджує, що гліфосат «практично нетоксичний» (Bai \& Ogbourne, 2016). Проте все більше досліджень вказують на ризики для здоров'я, пов'язані як iз Раундапом, так і $з$ препаратами на основі гліфосату. Міжнародна агенція з досліджень раку (IARC) у 2017 році назвала гліфосат «ймовірно канцерогенним» для людини. У 2018 році компанія Bayer придбала право власності на виробництво Раундапу у компанії Monsanto.

Гліфосат не має сільськогосподарсько значущого впливу на грунтову мікробіоту (Duke, 2020). Порівняно 3 альтернативними синтетичними гербіцидами гліфосат має менший коефіцієнт впливу на довкілля (Duke, 2020). Проте дослідження останніх років ставлять під сумнів безпеку цього препарату (Vandenberg et al., 2017). Під час забруднення корму максимальними дозами цього пестициду $\left(2,8 \cdot 10^{-1}, 2,8 \cdot 10^{-2}\right.$ і $2,8 \cdot 10^{-3}$ мг ізопропіламінова сіль гліфосату/Г підстилки) особини R. kessleri пришвидшують інтенсивність живлення. За дії Раундапу не виявлено достовірних змін маси тіла диплопод протягом експерименту. Дві наведені вище максимальні концентрації гербіциду збільшують темпи утворення екскрементів диплоподами (Kozak et al., 2020). Також у лабораторних умовах вивчали дію різних концентрацій препарату «Ураган Форте» (діюча речовина - калійна сіль гліфосату) на диплопод. Так, під час впливу препарату «Ураган Форте» у концентрації $3 \cdot 10^{-3}$ мг/Г підстилки багатоніжки $R$. kessleri збільшують темпи споживання корму. Гербіцид в усіх досліджених концентраціях не змінюе масу тіла багатоніжок. Калійна сіль гліфосату спричиняє збільшення продукції екскрементів у багатоніжок (Kozak et al., 2020).

Токсичність гліфосату також досліджена для водних безхребетних: комплекси гліфосат-Сu (II) зменшують (Hansen, Roslev, 2016) швидкість плавання та збільшують неактивний час Daphnia magna Straus, 1820. De Melo Tarouco et al. (2017) вказують на токсичний вплив Раундапу на поліхету Laeonereis acuta (Treadwell, 1923) (Phyllodocida, Nereididae), зниження концентрації активних форм кисню та зменшення антиоксидантної здатності іiі гемолімфи щодо пероксидних радикалів. Раундап також впливає на холінергічні синапси нервової системи L. acuta (De Melo Tarouco et al., 2017).

\section{Вилив інсектицидів та акарицидів на диплопод}

Вплив інсектицидів на грунтових членистоногих i дощових черв'яків у польових умовах вивчали Ghosal \& Hati (2019). Вони виявили зниження чисельності різних видів безхребетних - мешканців грунту (на 14,0\%), а також максимальну токсичність імідаклоприду щодо Eisenia fetida (Savigny, 1826) (Opisthopora, Lumbricidae) Під час моніторингу 2005-2012 років комах, які імігрували 3 Азії до Японії, Matsumura et al. (2013) виявили специфічну стійкість Nilaparvata lugens (Stål, 1854) (Hemiptera, Delphacidae) до імідаклоприду, LD 50 збільшилася 32005 $(0,7$ мкг/г) до 2012 року $(98,5$ мкг/г) у 140,7 разу. Denecke et al. (2017) показали надмірну експресію гена Cyp6g2 у 
центральній нервовій системі, який одночасно метаболізує імідаклоприд i надає стійкості до нього Drosophila melanogaster Meigen, 1830 (Diptera, Drosophilidae). Chen et al. (2017) вказують, що в межах субодиниці нікотинового ацетилхолінового рецептора виявлено мутацію $R 81 T$, що відповідає за стійкість до імідаклоприду в Aphis gossypii Glover, 1877 (Hemiptera, Aphididae). За дії максимальних досліджених концентрацій препарату «Біотлін» (діюча речовина - імідаклоприд) у концентраціях $1,2 \cdot 10^{-1}$ i $1,2 \cdot 10^{-2}$ мг/г підстилки маса тіла диплоподи R. kessleri не змінюється. Особини цього виду знижують темпи утворення екскрементів в усіх варіантах досліду (Kozak et al., 2020).

Диметоат, «БІ-58» - необоротний інгібітор ацетилхолінестерази, необхідної для функціонування центральної нервової системи (Alam et al., 2017; Ega et al., 2019). Ibrahim et al. (2019) під час впливу трьох концентрацій диметоату (1, 3 та 5 ppm) у вишневому саду та лабораторному експерименті виявили зменшення кількості живих личинок Caliroa cerasi Linnaeus, 1758 (Hymenoptera, Tenthredinidae). Ibrahim et al. (2020) вказують на негативний вплив $40 \%$ диметоату, що спричиняе загибель Aonidiella aurantii (Maskell, 1879) (Hemiptera, Diaspididae), Phyllocnistis citrella Stainton, 1856 (Lepidoptera, Gracillariidae) та Aleurothrixus floccosus (Maskell, 1896) (Homoptera, Aleyrodidae) - 86,9 \%, 87,2 \% та 86,0 \% смертності відповідно. Препарат «БІ-58» (діюча речовина - диметоат) порівняно з контролем не збільшує темпів розкладання підстилки диплоподами (Kozak et al., 2020). Максимальні концентрації диметоату $\left(2,4 \cdot 10^{-2}\right.$ до $2,4 \cdot 10^{-1}$ мг/г підстилки) спричиняють зменшення маси тіла $R$. kessleri. Під час зростання концентрації цього інсектициду в кормі швидкість утворення екскрементів знижується (Kozak et al., 2020).

Rumbos et al. (2018) встановили повну загибель дорослих Sitophilus granarius (Linnaeus, 1758) (Coleoptera, Curculionidae) під час обробки пшениці емульгованим концентратом і суспензією капсул двох доз (2 та 4 мг/кг) піриміфос-метилу. Протягом експерименту також спостерігали загибель Tribolium confusum Jacquelin du Val, 1863 (Coleoptera, Tenebrionidae) та Rhyzopertha dominica (Fabricius, 1792) (Coleoptera, Bostrichidae), що не досягала $100 \%$ (Rumbos et al., 2018). 72-годинний вплив цієї речовини на самиць Tribolium castaneum (Herbst, 1797) (Coleoptera, Tenebrionidae) знижує швидкість розмноження потомства та згубно впливає на життєздатність нащадків (Skourti et al., 2020). Francis et al. (2020) виявили резистентність семи популяцій Aedes aegypti (Linnaeus in Hasselquist, 1762) (Diptera, Culicidae) до піриміфос-метилу $(0,21 \%)$ : смертність від цієї речовини досягає 47,1\%. Kozak et al. (2020) вказують, що максимальні концентрації цього інсектициду $\left(3 \cdot 10^{-2}\right.$ i $3 \cdot 10^{-1}$ мг/Г підстилки) спричиняють 100\%-ву загибель $R$. kessleri. Низькі концентрації препарату «Актеллік» (діюча речовина піриміфос-метил) $3 \cdot 10^{-3} \quad$ мг/Г підстилки $\quad$ зумовлюють зупинку живлення диплопод, щодобово знижують масу їх тіла та зменшують інтенсивність утворення екскрементів на $0,07 \%$ і 5,83 \% відповідно.

Дослідження Hardman et al. (2003), проведені у 19901998 роках у яблуневих садах, вказують на токсичний вплив пропаргіту на Typhlodromus pyri Scheuten, 1857 (Mesostigmata, Phytoseiidae). Він ефективний (Milenković, Marcic, 2012) для боротьби 3 малиновим кліщем Phyllocoptes gracilis (Nalepa, 1891) (Trombidiformes, Eriophyidae). Сублетальні концентрації ( $\mathrm{LC}_{10}, \mathrm{LC}_{20}$ та $\left.\mathrm{LC}_{30}\right)$ пропаргіту (Omite ${ }^{\circledR} 57 \%$ EC, Mahan, Іран) впливають на тривалість життя, плодючість і зменшують тривалість яйцекладки Typhlodromips swirskii (Athias-Henriot, 1962) (Mesostigmata, Phytoseiidae). Kozak et al. (2020) встановили, що препарат Omite ${ }^{\mathbb{B}}$ (діюча речовина - пропаргіт) гальмує живлення більшості екземплярів багатоніжок за зростання концентрації цього інсектициду порівняно 3 контролем. За концентрації 3,6 $10^{-1}$ мг пропаргіту/г підстилки маса тіла диплопод зменшується на $0,57 \%$ щодоби, а темпи утворення екскрементів знижуються на 9,71\% (Kozak et al., 2020).

Циперметрин - інсектицид, що застосовують у сільському господарстві для зберігання зернових продуктів. Це швидкодіючий нейротоксин комах. Дослідження Attia et al. (2020) показали, що шкідники пшениці Sitophilus oryzae (Linnaeus, 1763) (Coleoptera, Curculionidae) та Tribolium castaneum (Herbst, 1797) (Coleoptera, Tenebrionidae) чутливі до циперметрину. Цей інсектицид надзвичайно токсичний для Microplitis croceipes (Cresson, 1872) (Hymenoptera, Braconidae), спричиняє 100 \% загибель цих особин (Tillman, 1995). Максимальна досліджена концентрація $3 \cdot 10^{-1}$ мг хлорпіріфосу на 1 г підстилки викликає повну загибель диплопод R. kessleri. Препарат «Нуррел Д» (діючі речовини - хлоропірифос і циперметрин) за концентрації $3 \cdot 10^{-2}$ мг хлорпіріфосу на 1 г підстилки (Kozak et al., 2020) спричиняє щодобове зменшення маси тіла та екскрементів диплопод на $0,34 \%$ і 0,80 \% відповідно.

\section{Вилив фунгіцидів на диплопод}

Застосування мефеноксаму в концентраціях 0,24 \% та 0,47\% (Ridomil ${ }^{\circledR}$ Gold 4 EC, Ciba-Geigy Corporation) на цитрусових у Флориді не має очевидних шкідливих наслідків як для імаго, так і для виживання личинок сонечок Cycloneda sanguinea (Linnaeus, 1763) та Harmonia axyridis (Pallas, 1773) (Coleoptera, Coccinellidae) (Michaud, 2001). У лабораторних умовах мефеноксам збільшує тривалість протонімфальної стадії (у 1,2-1,8 разу), також впливає на тривалість наступних стадій життя, час попереднього визрівання яєць, період яйцекладки та час постембріонального розвитку Stratiolaelaps scimitus Berlese, 1892 (Mesostigmata, Laelapidae). 72-годинний вплив мефеноксаму спричиняє загибель $27,5 \%$ S. scimitus (Cabrera et al., 2004). За дії мінімальних концентрацій $\left(4 \cdot 10^{-3}\right.$ мг/Г підстилки) препарату Ridomil ${ }^{\circledR}$ Gold 4 EC (діючі речовини - манкоцеб і мефеноксам) Kozak et al. (2020) виявили, що живлення багатоніжок не змінюється, а за збільшення концентрації цього препарату до $4 \cdot 10^{-2} \mathrm{Mг} / \Gamma$ i вище споживання корму припиняється. Маса тіла диплопод достовірно не змінюється. Процес утворення екскрементів знижується на 4,62 \% щодобово за впливу цього препарату у найвищій концентрації (Kozak et al., 2020).

Манкоцеб та ще 7 фунгіцидів Stanley et al. (2015) визнані безпечнішими, порівняно 3 іншими дослідженими пестицидами відносно Apis mellifera Linnaeus, 1758 та A. cerana Fabricius, 1793 (Hymenoptera, Apidae). Цей експеримент проведено шляхом прямого (обприскування рослин гірчиці у горшках) та опосередкованого (забруднення фільтрувального паперу) впливу на бджіл. За дії препарату «Паннкоцеб 80ВП» (діюча речовина манкоцеб) у концентрації $4,8 \cdot 10^{-2}$ мг манкоцебу/г підстилки спостерігали припинення живлення багатоніжок (Kozak et al., 2020). Манкоцеб достовірно не впливає на масу тіла R. kessleri у лабораторному експерименті. Середня концентрація $\left(4.8 \cdot 10^{-2}\right.$ мг/Г підстилки) цього фунгіциду вдвічі знижує кількість фекалій диплопод у лабораторному експерименті (Kozak et al., 2020).

Препарат «Сірка, що змочується» стає ефективним за умов $27,5^{\circ} \mathrm{C}$ і $75 \%$ вологості. Акарицидна дія сульфуру посилюється зі збільшенням цих показників до максимальних $\left(35^{\circ} \mathrm{C}\right.$ та $90 \%$ вологості). У межах температур і вологості $20{ }^{\circ} \mathrm{C} / 30 \%$ та $35{ }^{\circ} \mathrm{C} / 90 \%$ Auger et al. (2003) виявили повну смертність незрілих Tetranychus urticae C. L. Koch, 1836 (Trombidiformes, Tetranychidae) (від стадії протонімфи до телеохризалісу). У цих умовах самки гинули ще до завершення експерименту. До сульфуру яйця менш сприйнятливі, ніж самки, які, у свою чергу, були менш сприйнятливі, ніж юнацькі стадії (Auger et al., 2003). Cochliomyia hominivorax (Coquerel, 1858) 
(Diptera, Calliphoridae) - муха, яка спричиняє первинні міази у великої рогатої худоби в Бразилії. Ї̈̈ личинки розвиваються в живих тканинах хазяїна, викликаючи каліцтво, та навіть можуть призвести до загибелі ссавців. Під час лікування міазів різними гомеопатичними препаратами De Barros et al. (2019) встановили, що «Sulfur $12 \mathrm{cH»} \mathrm{найефективніший} \mathrm{для} \mathrm{боротьби} \mathrm{з} \mathrm{цими} \mathrm{паразитами} \mathrm{-}$ зумовлює 94,6\%-ну їхню загибель. «Тіовіт Джет» (діюча речовина - сульфур) не знижує живлення особин багатоніжки R. kessleri. Додавання до підстилки цього препарату збільшує масу тіла з 0,7 мг/добу в контролі до 1,5-1,7 мг/добу за концентрації сульфуру $4,8 \cdot 10^{-1}$ $4,8 \cdot 10^{-3}$ мг/г підстилки. У градієнті концентрацій фунгіциду не відмічено достовірних змін інтенсивності утворення екскрементів диплопод (Kozak et al., 2020).

Тебуконазол токсичний для членистоногих. Так, 0,40 мг/л тебуконазолу зменшує масу кокона, масу оболонки кокона та швидкість утворення оболонки кокона Bombyx mori Linnaeus, 1758 (Lepidoptera, Bombycidae) на $6,8 \%, 11,8 \%$ та 4,4\% відповідно (Li et al., 2019). Цей препарат пошкоджує слинні залози шовковичного шовкопряда, знижує регуляцію транскрипції генів (Fibh, Fibl, P25, Ser2, Ser3), які беруть участь у синтезі білка в слинних залозах (Li et al., 2019). Концентрація 0,05 мг/л або вища S-тебуконазолу достовірно знижує розмноження та впливає на розвиток Daphnia magna Straus, 1820 (Cladocera, Daphniidae) (Qi et al., 2015). Kozak et al. (2020) встановили, що максимальна досліджена концентрація препарату «Фалкон» (діючі речовини - тебуконазол, тріадіменол і спіроксамін) зумовлює припинення живлення R. kessleri. За дії цього препарату в усіх варіантах досліду маса тіла диплопод не відрізняється від контрольних значень. Добова продукція екскрементів знижується на $0,68 \%$ вже за мінімальної концентрації $1,1 \cdot 10^{-2}$ мг тебуконазолу на 1 г підстилки (Kozak et al., 2020).

В експериментах із дослідження гострої токсичності (стандарт LC 50,4 доби) або імпульсної токсичності (загальна тривалість 10 діб) пропіконазолу на Gammarus pulex (Linnaeus, 1758) (Malacostraca, Amphipoda) Nyman et al. (2012) встановили, що імпульсна дія вбиває більше організмів, ніж вплив постійної концентрації. Летальний i сублетальний токсичний ефект пропіконазолу протягом різних сезонів на робочих бджіл Apis mellifera продемонстрував виникнення у комах поганої координації рухів, гіперактивності та апатії медоносних бджіл, навіть у польових реалістичних дозах у цієї речовини найгірший сценарій. Робочі бджоли - кормозбирачі, сприйнятливіші до пестицидів: зареєстровано вчетверо більший ефект на них, ніж на бджіл у вулику (Tosi \& Nieh, 2019). У лабораторних умовах Kozak et al. (2020) виявили, що найменша концентрація $1,5 \cdot 10^{-3} \mathrm{Mг} / \Gamma$ підстилки препарату «Тілт» (діюча речовина пропіконазол) спричиняє припинення живлення диплопод. За цієї концентрації фунгіциду маса тіла особин $R$. kessleri знижується на $0,20 \%$ за добу. Інтенсивність утворення екскрементів під час зростання концентрації пропіконазолу достовірно не змінюється (Kozak et al., 2020).

Результати грунтовного аналізу зразків диких бджіл різних видів, а також медоносних бджіл із пасік у 23 штатах США та однієї провінції Канади протягом цілого вегетаційного періоду (Mullin et al., 2010) свідчать про відносно слабкий вплив ципродинілу на цих комах. Бджоли піддаються дії засобів захисту рослин із перших днів личинкового розвитку. Після оброблення малини сорту Лашка ципродинілом його сліди знайдено в листі $\left(0,001\right.$ мкг $/ \mathrm{cm}^{2}$ листя $)$ та квітках $(0,022$ мкг/квітку). У зразках бджіл, розплоді та меді знайдено залишки цієї речовини, що в жодному з досліджень не перевищує ГДК (Piechowicz et al., 2018). Kozak et al. (2020) встановили, що препарат «Хорус» (діюча речовина ципродиніл) достовірно не впливає на споживання корму диплоподами в концентраї $4,5 \cdot 10^{-1}$ мг/г підстилки. Мінімальна концентрація $4,5 \cdot 10^{-3}$ мг ципродинілу/г підстилки спричиняє максимальне збільшення маси тіла R. kessleri на 0,37 \% щодобово, а збільшення концентрації цієї речовини у кормі не гальмує процес дефекації цього виду диплопод.

\section{Вилив паразитів на організми диплопод}

Своєрідний вплив на організми диплопод чинять нематоди, кліщі та грегарини. У кишечнику, трахеолах $\mathrm{i}$ сполучній тканині Oxidus gracilis (C. L. Koch, 1847) (Polydesmida, Paradoxosomatidae) паразитують Steinernema carpocapsae (Weiser, 1955) (Rhabditida, Steinernematidae) та Heterorhabditis heliothidis (Khan, Brooks \& Hirschmann, 1976) (Rhabditoidea, Heterorhabditidae). Ці нематоди гальмують імунні захисні реакції господаря (Poinar \& Thomas, 1985). Дослідженнями Malysheva et al. (2020), проведеними в Республіці Адигея (Російська Федерація), виявлено, що в задній кишці Pachyiulus krivolutsky Golovatch, 1977 (Julida, Julidae) паразитує Severianoia pachyiuli Malysheva et al., 2020 (Oxyuridomorpha). Morffe \& Hasegawa (2017) з префектури Айчі, що в Японії, виявили в задньому відділі кишечника полідесмідної багатоніжки Parafontaria laminata (Attems, 1909) (Polydesmida, Xystodesmidae) паразитуючу нематоду Rhigonema naylae Morffe \& Hasegawa, 2017 (Rhigonematomorpha, Rhigonematidae).

Iз 44 проаналізованих особин Narceus gordanus Chamberlin, 1943 (Spirobolida, Spirobolidae), що мешкають на півострові Флорида, у 33 (75 \%) кишечниках $N$. gordanus виявлено паразитуючих нематод Heth pivari Phillips et al., 2020 (Oxyuridomorpha, Hethidae) (Phillips et al., 2020). У Північно-Східній Австралії Baker \& Seeman (2008) описали Neomegistus remus Baker, Seeman, 2008 (Mesostigmata, Paramegistidae) на багатоніжці Proporobolus sp. (Spirobolida, Rhinocricidae). У Південній Австралії мікроботрофну нематоду Rhabditis necromena (Sudhaus, Schulte, 1989) (Nematoda, Rhabditidae), господар якої Akamptogonus novarae (Humbert, DeSaussure, 1869) (Polydesmida, Paradoxosomatidae), використовують як біологічний засіб боротьби 3 інтродукованою багатоніжкою Ommatoiulus moreletii (Lucas, 1860) (Julida, Julidae). Ця нематода паразитує всередині гемоцелю свого хазяїна поки він не загине, потім $R$. nесromena відновлює свій розвиток після живлення бактеріями, які присутні в трупі хазяїна (Schulte, 1989). McKillup et al. (1991) у лабораторних і польових експериментах виявили, що нематода $R$. necromena - ефективний засіб біологічного контролю проти диплоподи Spinotarsus caboverdus Pierrard, 1987 (Spirostreptida, Odontopygidae). Ефективність цього методу в лабораторних умовах досить висока, а в польовому експерименті зараження багатоніжок $S$. caboverdus нематодами $R$. necromena виявилося надзвичайно низьким (McKillup et al., 1991).

Організми диплопод населяють грегарини, які відносяться до двох рядів (Eugregarinorida та Neogregarinorida), п'яти родин (Actinocephalidae, Cnemidosporidae, Monoductidae, Stenophoridae та Lipotrophidae) та восьми родів (Actinocephalus, Amphoroides, Cnemidospora, Monoductus, Stenoductus, Fonsecaia та Hyalosporina). Actinocephalus blanuli Triffit, 1927 (Eugregarinorida, Actinocephalidae), Amphoroides polydesmi (Léger, 1892) Labbé, 1899 (Eugregarinorida, Actinocephalidae), Fonsecaia polymorpha Pinto, 1918 (Eugregarinorida, Stenophoridae), Hyalosporina cambolopsisae Chakravarty, 1935 (Eugregarinorida, Stenophoridae), Monoductus lunatus Ray, Chakravarty, 1933 (Eugregarinorida, Monoductidae), Stenoductus penneri Ramachandran, 1975 (Eugregarinorida, Monoductidae), Cnemidospora lutea A. Schneider, 1882 (Eugregarinorida, Cnemidosporidae), Chakravartiella sugereiformes Misra, Raychaudhury, 1973 (Eugregarinorida, Cnemidosporidae), Lipotropha mattei Tuzet, Manier (1958) (Eugregarinorida, Lipotrophidae) - грегарини, які паразитують у представниках класу Diplopoda. 
У диплоподах Ktenostreptus culcurutus Demange, 1962 (Spirostreptida, Harpagophoridae) знайдено грегарини Stenoductus ktenostrepti Janardanan, 1987 (Eugregarinida, Stenophoridae), споронти яких досягають 2361 на 432 мкм (Janardanan, 1987). Організм диплоподи Carlogonus palmatus Demange, 1977 (Spirostreptida, Harpagophoridae) населяють грегарини Stenoductus carlogoni Janardanan, Ramachandran, 1987 (Eugregarinorida, Stenophoridae) (Janardanan, Ramachandran, 1987). У кишечнику індійських багатоніжок Trigoniulus qoesi (Porath, 1876) (Spirobolida, Pachybolidae) та Xenobolus acuticonus Attems, 1936 (Spirobolida, Pachybolidae) Janardanan, Ramachandran (1982) виявили паразитуючих грегарин Stenoductus trigoniuli Janardanan, Ramachandran, 1982 (Eugregarinorida, Stenophoridae). Інфіковані епітеліальні клітини середньої кишки $T$. qoesi демонструють прогресуючу гіпертрофію та накопичують ліпідні кульки. Паразит не чинить помітного впливу на ДНК, вуглеводи, вміст білка або РНК у заражених клітинах (Janardanan, Ramachandran, 1982).

У кишечнику $R$ kessleri (Lohmander, 1927) виявлено гамонтів Stenophora daulphinia Watson, 1916, S. juli (Frantzius, 1846) Labbe, 1899 та S. julipusilli (Leidy, 1853) Crawley, 1903 (Eugregarinorida, Stenophoridae). Гамонти та сизигіï S. julipusilli знайдено у 79,2 \% диплопод, 20,8 \% не заражені грегаринами (Brygadyrenko \& Svyrydchenko, 2015). Молодші особини R. kessleri менше заражені гамонтами, ніж особини середнього та старшого віку. Ступінь зараження гамонтами $S$. julipusilli особин R. kessleri двох статей суттєво не відрізняється. Сапрофаги 3 незначною інвазією (1-8 гамонтів) живляться інтенсивніше на 29,0 \%, а із середньою та високою менше на 8,0 \% порівняно 3 неінвазованими особинами. Стать R. kessleri не впливає на споживання корму, зміну маси тіла або масу фекалій диплопод, заражених грегаринами (Brygadyrenko, Svyrydchenko, 2015).

\section{Комплексний вплив урбанізації на диплопод}

У великих містах України на диплопод помітний вплив чинять одночасно декілька факторів (пестициди, важкі метали, стійкі органічні забруднювачі, ущільнення грунту, фрагментація біотопів, рекреація, зміна видового складу автотрофів, спалювання листяного опаду та підстилки тощо). Через вплив різноманітних факторів на живі організми, які існують на урбанізованих територіях, чисельність диплопод низька, а їх видовий склад досить збіднений (Pakhomov, Brygadyrenko, 2005). Так, у трофічній структурі лісопаркового насадження на території Ботанічного саду Дніпровського національного університету імені Олеся Гончара зустрічається лише один вид багатоніжок - Sch. dmitriewi, який становить 1,01 \% від щільності грунтової мезофауни (Zhukov et al., 2014). У цілому на урбанізованих територіях чисельність диплопод низька, але на окремих ділянках їх кількість чомусь збільшується, навіть поблизу теплоелектростанцій, де у зв'язку 3 дією різних полютантів чисельність багатоніжок мала б зменшуватись. Так, поблизу Придніпровської теплової електростанції Korolev et al. (2009) виявили збіднений видовий склад Julidae, який представлений лише одним видом - M. sjaelandicum зі значною чисельністю, що становить 4,5 екз./10 пастко-діб. На організми диплопод діє багато факторів, що в різні роки чи навіть сезони на одній чи іншій території по-різному впливають на багатоніжок. Так, із чотирьох досліджених пробних площ, розташованих у межах Дніпра, найменша чисельність сапрофагів зареєстрована поблизу ВАТ «Дніпрошина» (Korolev et al., 2009).

У центрі міста Дніпро, на схилах східної експозиції Червоноповстанської балки (урботехнозем) у трофічній структурі домінують сапрофаги. На цій території знайдено лише два види багатоніжок. Чисельність диплопод невисока і від загальної чисельності грунтових безхребетних становить 5,4\% і 0,8\% Sch. dmitriewi та M. rossicum відповідно (Kunah et al., 2014). Через нестачу вологи у міських тополевих насадженнях виявлене низьке різноманіття та деградована трофічна та розмірна структура угруповань грунтових безхребетних (Faly et al., 2017). За домінуванням у таксономічній структурі Julidae займають п'яте місце після Formicidae, Pulmonata, Porcellionidae та Lygaeidae. У балці Тунельна (південна частина міста Дніпро) диплоподи представлені лише одним видом - Sch. dmitriewi (Faly et al., 2017). Таким чином, на урбанізованих територіях загальна чисельність диплопод дуже низька, вони трапляються на площі 5-15 \% рекреаційних ділянок (парки, балки, лісосмуги) великих міст степової зони України. Дуже рідко на незначних територіях відносна чисельність диплопод зростає до максимальної, характерної для природних ділянок.

\section{Поширення диплопод на рекультивованих територіях}

Гірничодобувна промисловість крім позитивного внеску у розвиток економіки регіону призводить до негативних наслідків для довкілля (руйнування грунтового покриву, просідання земної поверхні, затоплення прилеглих територій, скупчення високомінералізованих шахтних вод, накопичення та зберігання відвальних порід, скупчення шкідливих хімічних речовин у грунті). Надходження шахтних порід до екосистем викликає збіднення видового складу біоценозів. Так, на ділянках рекультивації важкі метали та інші речовини потрапляють у рослини, а звідти під час живлення надходять до організму сапрофагів, де поступово накопичуються i спричиняють інтоксикацію. Покриви у диплопод складаються 3 кальцію і карбонату, а хімікати 3 шахтних відвалів їх руйнують. На чотирьох ділянках в антропогенно трансформованих умовах Криворіжжя Kulbachko et al. (2010) розглянули таксономічний склад, структуру домінування, співвідношення функціональних груп грунтових безхребетних. На території ЗАТ «Криворізький суриковий завод» виявлено 17 видів грунтових безхребетних. Найменша чисельність зареєстрована для двопарноногих багатоніжок (4 екз./ $\left.\mathrm{M}^{2}\right)$ (Kulbachko et al., 2010). Присутність двопарноногих багатоніжок у грунтосумішах (шахтна порода, чорнозем звичайний, підстилка 3 листя Robinia pseudoacacia L., $1753)$ сприяє інтенсивному виділенню вуглекислого газу як однієї з характеристик біологічної активності грунтів (Kulbachko et al., 2007). Встановлено статистично достовірний вплив трикомпонентної суміші на інтенсивність грунтового «дихання» (Pakhomov et al., 2008). Під час додавання до шахтної породи підстилки 3 $R$. pseudoacacia зростає швидкість виділення $\mathrm{CO}_{2}$, а це може спричинити формування відповідних умов для існування тварин (Kulbachko et al., 2007). Підтоплення лісових екосистем шахтними водами Західного Донбасу призводить до зменшення кількості видів та індексів видового різноманіття підстилкової мезофауни. Так, диплоподи представлені лише одним видом - R. kessleri зі значною чисельністю (31,2 \% від сумарної чисельності герпетобію) (Brygadyrenko, Faly, 2009).

Трофічні переваги $M$. rossicum на різних типах шахтної породи та гумусованому шарі чорнозему звичайного, що використовують у рекультивації як насипний грунт, залежать від актуальної кислотності (Pakhomov et al., $2008)$. Частота знаходження сапрофагів низька $(23,4-30,7$ \%); вона зменшуєтся від нейтральної до кислої реакції розчину штучних грунтосумішей (чорнозем звичайний $\mathrm{i}$ «перегоріла» шахтна порода) на листяному опаді клена гостролистого Acer platanoides L. та робінії псевдоакації $R$. pseudoacacia порівняно 3 ялівцем віргінським Juniperus virginiana L. На шахтній породі (кислий субстрат) диплоподи інтенсивніше споживають кленовий $(41,1 \%)$ та робінієвий $(34,0 \%)$ листяний опад, а ялівцевий опад слабкіше $(24,9$ \%) (Kulbachko \& Didur, 2012). У двопарноногих багатоніжок, які мешкають на шахтній 
породі, виявлено достовірне зменшення маси тіла порівняно з контрольними ділянками (Pakhomov et al., 2008).

у м. Орджонікідзе в техногенних біоценозах зареєстровано два представники класу Diplopoda (Prokopenko, Zhukov, 2011). R. kessleri знайдено на всіх 11 ділянках рекультивації - усіх типах технозему та рослинного покриву. M. kievense зустрічається тільки на трьох ділянках. На рекультивованих територіях із рослинним покривом формуються екологічні умови, придатні для існування специфічних груп герпетобіонтів (Prokopenko, Zhukov, 2011). У Науково-дослідному центрі Дніпровського державного аграрно-економічного університету на техноземах у місті Покров у 2013-2015 pp. зафіксовано 202 види безхребетних (членистоногих i молюсків). Найпоширеніша родина із класу Diplopoda Julidae; вона представлена лише одним видом - R. kessleri (Pakhomov et al., 2019).

Таким чином, диплоподи відіграють істотну роль для оптимізації процесів грунтоутворення на ділянках рекультивації.

\section{Висновки}

Диплоподи - важливі грунтові організми, які мінералізують грунт у лісових екосистемах степової зони України. Лімітуючі фактори поширення багатоніжок у Степу - ступінь зволоження грунту (оптимальне мезофільні умови зволоження) та освітленість території існування (чисельність вища за умов зімкненого деревного чи чагарникового намету). 3 огляду на наведене вище, пріоритетними антропогенними чинниками на території степової зони України є техногенне (важкі метали) та агрогенне (пестициди) хімічне забруднення територій. Полютанти по-різному впливають на організми багатоніжок. Хімікати впливають на інтенсивність живлення, змінюють масу тіла, а в найвищих концентраціях досить токсичні для диплопод i можуть викликати їх загибель. Найшкідливіші метали для грунтових безхребетних організмів - нікель, свинець $\mathrm{i}$ кадмій, що в помірних та високих концентраціях здатні спричиняти загибель диплопод.

Пестициди, що застосовують в агроценозах для захисту рослин, потрапляють до лісових екосистем, розташованих поряд, i спричиняють зменшення чисельності особин певного таксону диплопод, зниження видового різноманіття мезофауни. Високі концентрації піриміфосметилу, сульфуру, імідаклоприду, циперметрину, пропіконазолу та диметоату спричиняють майже 100\%-ну смертність безхребетних організмів. За впливу урбанізації площі біотопів, в яких поширені диплоподи, зменшуються. Видовий склад і чисельність багатоніжок знижуються на рекультивованих ділянках i урбанізованих територіях. Смертність диплопод зумовлюють також паразити (нематоди та грегарини), що оселяються в їхніх організмах.

Аналіз літературних джерел показав, що дослідження цього питання досить актуальне та потребує проведення нових експериментів для виявлення таких концентрацій забруднюючих речовин, що чинитимуть помірний вплив на довкілля. Щоб зменшити негативний вплив викидів хімічних речовин, що надходять у навколишнє середовище від промислових підприємств, потрібно здійснювати регулярний моніторинг індустріальних об'єктів та дотримуватися режимів використання та відновлення буферних зон цих підприємств.

\section{References}

Alam, M., Sumra, M. W., Ahmad, D., Shah, R. M., Binyameen, M., Shad, A. S. (2017). Selection, realized heritability, and fitness cost associated with dimethoate resistance in a field population of Culex quinquefasciatus
(Diptera: Culicidae). Journal of Economic Entomology 110(3), 1252-1258.

Attia, M. A., Wahba, T. F., Shaarawy, N., Moustafa, F. I., Guedes, R. N. C., Dewer, Y. (2020). Stored grain pest prevalence and insecticide resistance in Egyptian populations of the red flour beetle Tribolium castaneum (Herbst) and the rice weevil Sitophilus oryzae (L.). Journal of Stored Products Research 87, 101611.

Auger, P., Guichou, S., Kreiter, S. (2003). Variations in acaricidal effect of wettable sulfur on Tetranychus urticae (Acari: Tetranychidae): effect of temperature, humidity and life stage. Pest Management Science 59(5), 559-565.

Bai, S. H., Ogbourne, S. M. (2016). Glyphosate: Environmental contamination, toxicity and potential risks to human health via food contamination. Environmental Science and Pollution Research 23(19), 18988-19001.

Baker, M., Seeman, O. (2008). Mites and millipedes: a new Neomegistus (Acari: Mesostigmata: Paramegistidae) from Australia. Systematic and Applied Acarology 13, 204-213.

Brygadyrenko, V, Ivanyshyn, V. (2015). Changes in the body mass of Megaphyllum kievense (Diplopoda, Julidae) and the granulometric composition of leaf litter subject to different concentrations of copper. Journal of Forest Science 61(9), 369-376.

Brygadyrenko, V. V. (2004). Ispol'zovanie imitacionnogo modelirovaniya pri izuchenii populyacij Rossiulus kessleri (Diplopoda, Julidae) [The use of simulation in the study populations Rossiulus kessleri (Diplopoda, Julidae)]. Visnyk of Dnipropetrovsk University. Biology, Ecology 12, 15-22 (in Russian).

Brygadyrenko, V. V. (2006). Vozmozhnosti ispol'zovaniya napochvennykh bespozvonochnykh dlya indikatsii gradatsiy uvlazhneniya edafotopa $\mathrm{v}$ lesnykh ekosistemakh [The possibility to use soil invertebrates to indicate soil moisture gradations in the forest ecosystems]. Visnyk of Dnipropetrovsk University. Biology, Ecology 14(1), 21-26 (in Russian).

Brygadyrenko, V. V. (2014). Influence of soil moisture on litter invertebrate community structure of pine forests of the steppe zone of Ukraine. Folia Oecologica 41(1), 8-16.

Brygadyrenko, V. V. (2015a). Vplyv umov zvolozhennja ta mineralizacii' g'runtovogo rozchynu na strukturu pidstylkovoi' mezofauny shyrokolystjanyh lisiv stepovoi' zony Ukrai'ny [Influence of moisture conditions and mineralization of soil solution on structure of litter macrofauna of the deciduous forests of Ukraine steppe zone]. Visnyk of Dnipropetrovsk University. Biology, Ecology 23(1), 50-65 (in Ukrainian).

Brygadyrenko, V. (2015b). Community structure of litter invertebrates of forest belt ecosystems in the Ukrainian steppe zone. International Journal of Environmental Research 9(4), 1183-1192.

Brygadyrenko V. V. (2016a). Vplyv potuzhnosti pidstylky na strukturu pidstylkovoyi mezofauny shyrokolystyanykh lisiv stepovoyi zony Ukrayiny [Influence of litter thickness on the structure of litter macrofauna of deciduous forests of Ukraine's steppe zone]. Visnyk of Dnipropetrovsk University. Biology, Ecology 24(1), 240-248 (in Ukrainian).

Brygadyrenko, V. V. (2016b). Effect of canopy density on litter invertebrate community structure in pine forests. Ekológia (Bratislava) 35(1), 90-102.

Brygadyrenko, V. V., Faly L. I. (2009). Vplyv pidtoplennya shakhtnymy vodamy na pidstylkovu mezofaunu zaplavnykh lisiv zakhidnoho Donbasu [The influence of submerging by coalmining water on leaf-litter fauna structure in salt soil forest of western Donbass]. Problems of bioindications and ecology 14(1), 90-100 (in Ukrainian).

Brygadyrenko, V. V., Ivanyshin, V. M. (2014). Vliyaniye soli zheleza na massu tela Megaphyllum kievense (Diplopoda, Julidae) i granulometricheskiy sostav podstilki $\mathrm{V}$ laboratornom eksperimente [Impact of ferric salt on body 
weight of Megaphyllum kievense (Diplopoda, Julidae) and litter granulometric composition in the laboratory experiment]. Visnyk of Dnipropetrovsk University. Biology, Ecology 22(1), 83-87 (in Russian).

Brygadyrenko, V. V., Komarov, O. S. (2008). Trofichna struktura pidstylkovoji mezofauny: rozpodil biomasy za trofichnymy rivniamy [Trophic structure of litter mesofauna: Biomass differentiation between trophic levels]. Visnyk of Dnipropetrovsk University. Biology, Ecology, 16(2), 12-23 (in Ukrainian).

Brygadyrenko, V. V., Svyrydchenko, A. O. (2015). Influence of the gregarine Stenophora julipusilli (Eugregarinorida, Stenophoridae) on the trophic activity of Rossiulus kessleri (Diplopoda, Julidae). Folia Oecologica 42(1), 10-20.

Cabrera, A. R., Cloyd, R. A., Zaborski, E. R. (2004). Effects of greenhouse pesticides on the soil-dwelling predatory mite Stratiolaelaps scimitus (Acari: Mesostigmata: Laelapidae) under laboratory conditions. Journal of Economic Entomology 97(3), 793-799.

Chen, X., Li, F., Chen, A., Ma, K., Liang, P., Liu, Y., Dunlun S., Gao, X. (2017). Both point mutations and low expression levels of the nicotinic acetylcholine receptor $\beta 1$ subunit are associated with imidacloprid resistance in an Aphis gossypii (Glover) population from a $\mathrm{Bt}$ cotton field in China. Pesticide Biochemistry and Physiology 141, 1-8.

De Barros, G. P., Seugling, J., Bricarello, P. A. (2019). Effect of homeopathic medicines and a nosode on larvae of Cochliomyia hominivorax (Diptera: Calliphoridae). Homeopathy, 108(03) 177-182.

De Melo, T. F., de Godoi, F. G. A., Velasques, R. R., da Silveira Guerreiro, A., Geihs, M. A., da Rosa, C. E. (2017). Effects of the herbicide Roundup on the polychaeta Laeonereis acuta: Cholinesterases and oxidative stress. Ecotoxicology and Environmental Safety, 135, 259-266.

Denecke, S., Fusetto, R., Martelli, F., Giang, A., Battlay, P., Fournier-Level, A., O' Hair, R. A., Batterham, P. (2017). Multiple P450s and variation in neuronal genes underpins the response to the insecticide imidacloprid in a population of Drosophila melanogaster. Scientific Reports 7(1), $\underline{11338 .}$.

Duke, S. O. (2020). Glyphosate: Environmental fate and impact. Weed Science 68(3), 201-207.

Ega, T. K., Al-Hamry, A., Kanoun, O., Lazarevic-Pasti, T., Bogdanovic, D. B., Pasti, I. A., Rodriguez, R. D., Sheremet, E., Paterno, L. G. (2019). Detection of dimethoate pesticide using layer by layer deposition of PDAC/GO on Ag electrode. 2019 16th International MultiConference on Systems, Signals \& Devices (SSD). Istanbul. Pp. 621-625.

Faly, L. I., Kolombar, T. M., Prokopenko, E. V., Pakhomov, O. Y., Brygadyrenko, V. V. (2017). Structure of litter macrofauna communities in poplar plantations in an urban ecosystem in Ukraine. Biosystems Diversity 25(1), 29-38.

Faly, L., Brygadyrenko, V. (2014). Patterns in the horizontal structure of litter invertebrate communities in windbreak plantations in the steppe zone of the Ukraine. Journal of Plant Protection Research 54(4), 414-420.

Francis, S., Campbell, T., McKenzie, S., Wright, D., Crawford, J., Hamilton, T., Huntley-Jones, S., Spence, S., Belemvire, A., Alavi, K., Torres Gutierrez, C. (2020). Screening of insecticide resistance in Aedes aegypti populations collected from parishes in Eastern Jamaica. PLoS Neglected Tropical Diseases, 14(7), e0008490.

Gangadhar, B., Naidu, G. R., Reddy, N. B. (2020). Toxic effects of glyphosate on environment and human health. In: G. V. Zyryanov, S. Santra, \& L. K. Sadieva (Ed.), Modern synthetic methodologies for creating drugs and functional materials, MOSM 2019: Proceedings of the III International Conference. American Institute of Physics Inc.

Ghosal, A., Hati, A. (2019). Impact of some new generation insecticides on soil arthropods in rice maize cropping system. The Journal of Basic and Applied Zoology 80(1), $\underline{1-8}$.

Hansen, L. R., Roslev, P. (2016). Behavioral responses of juvenile Daphnia magna after exposure to glyphosate and glyphosate-copper complexes. Aquatic Toxicology 179, 36-43.

Hardman, J., Franklin, J., Moreau, D., Bostanian, N. (2003). An index for selective toxicity of miticides to phytophagous mites and their predators based on orchard trials. Pest Management Science 59, 1321-1332.

Ibrahim, F., Hadush, T., Abraha, G., Alemu, A. (2020). Evaluation of some botanical extracts against major insect pests (Leafminer, Armored scale and Woolly Whitefly) of citrus plants in central zone of tigray, North Ethiopia. Momona Ethiopian Journal of Science 11(2), 258-275.

Ibrahim, M. A., Ibrahim, I., Al-Antary, T., Kaakeh, N. (2019). Evaluation of the susceptibility of four different cultivars for cherry slug Caliroa cerasion (L.) (Hymenoptera: Tenthredinidae). Fresenius Environmental Bulletin 28, 8783-8788.

Janardanan, K. P. (1987). Stenoductus ktenostrepti n. sp. (Apicomplexa: Cephalina) from the Millipede, Ktenostreptus calcaratus Demange. Archiv Für Protistenkunde 133(3-4), 295-299.

Janardanan, K. P., Ramachandran, P. (1987). Observations on the Polysaccharides of Stenoductus carlogoni (Cephalina: Monoductidae): a Cyto-Biochemical Analysis. Archiv Für Protistenkunde 133(1-2), 145-150.

Janardanan, K., Ramachandran, P. (1982). Studies on a new Cephaline Gregarine, Stenoductus trigoniuli $\mathrm{n}$. sp. With a Note on its Cytopathology. Archiv für Protistenkunde 125, 249-256.

Korolev, A. V., Pokhylenko, A. P., Shul'man, M. V. (2009). Osobennosti formirovaniya gerpetobiya biogeotsenozov urbanizirovannykh territoriy na primere Dnepropetrovska [Features of the formation of herpetobia in biogeocenoses of urbanized territories on the example of Dnepropetrovsk]. In: Engineering technologies and systems. Publishing House of National Reserch Mordovia State University, Saransk. Pp. 34-35 (in Russian).

Kozak, V. M., Brygadyrenko, V. V. (2018). Impact of cadmium and lead on Megaphyllum kievense (Diplopoda, Julidae) in a laboratory experiment. Biosystems Diversity 26(2), 128-131.

Kozak, V. M., Brygadyrenko, V. V., Romanenko E. R. (2020). Influence of herbicides, insecticides and fungicides on food consumption and body weight of Rossiulus kessleri (Diplopoda, Julidae). Biosystems Diversity 28(3), 272-280.

Kul'bachko, Y. L., Didur, O. O. (2012). Troficheskiye predpochteniya dvuparnonogikh mnogonozhek (Diplopoda) pri vosstanovlenii territoriy, narushennykh gornodobyvayushchey promyshlennost'yu [Trophic priorities of millipedes (Diplopoda) in process of rehabilitation of the territories disturbed by mining industry]. Visnyk of Dnipropetrovsk University. Biology, Ecology 20(2), 30-37 (in Russian).

Kulbachko, Y. L., Didur, O. A., Loza, I. M. (2007). Otsenka vliyaniya predstaviteley dvuparnonogikh mnogonozhek (Diplopoda) na emissiyu uglekislogo gaza model'nymi pochvosmesyami pri reshenii problem rekul'tivatsii narushennykh zemel' [Evaluation of the influence of representatives of two-legged centipedes (Diplopoda) on the emission of carbon dioxide by model soil mixtures in solving the problems of reclamation of disturbed lands]. Problems of ecology and nature protection of technogenic region 7, 93-99 (in Russian).

Kulbachko, Y. L., Didur, O. A., Loza, I. M. (2010). Osoblyvosti formuvannya fauny gruntovykh bezkhrebetnykh $\mathrm{v}$ antropotekhnohennykh umovakh Kryvorizhzhya [Features of forming an invertebrate fauna in technogen environment (Kriviy Rig)]. Problems of 
ecology and nature protection of technogenic region10(1), 128-132 (in Ukrainian).

Kulbachko, Y. L., Gasso, V. Y. (2008). Nakopleniye tyazhelykh metallov pochvennymi bespozvonochnymi razlichnykh funktsional'nykh grupp $\mathrm{v}$ zone deystviya margantsevoy obogatitel'noy fabriki [Accumulation of heavy metals by soil invertebrates of different functional groups in a zone of manganese concentrating mill's influence]. Problems of bioindications and ecology 13(2), 121-130 (in Russian).

Kunah, O. M. (2005). Struktura dominuvannya tvarynnoho naselennya gruntu tsentral'noyi zaplavy r. Samara v umovakh eksperymental'noho zabrudnennya vazhkymy metalamy [Structure of domination of fauna in soil of central flood plain of the Samara river in the conditions of experimental heavy metal pollution]. Visnyk of Dnipropetrovsk University. Biology, Ecology 2(13), 113-117 (in Ukrainian).

Kunah, O. N., Zhukov, A. V., Prokopenko, E. V., Balyuk, Y. A. (2008). Ekologicheskaya struktura zhivotnogo naseleniya bayraka Yatsev Yar [Ecological structure of the animal community of the Yatsev Yar ravine]. Visnyk of Dnipropetrovsk University. Biology, Ecology 16(2), 74-85 (in Russian).

Kunah, O., Zhukov, O., Baljuk, J., Fediushko, M. (2014). Ekomorficheskoye raznoobraziye i prostranstvennaya organizatsiya soobshchestva mezopedobiontov urbotekhnozema [Ecomorphic and spatial organization of the urbanozem mesopedobionts]. Visnyk of Dnipro state agrarian and economic university. BIologycal sciences 1, 31-41 (in Russian).

Li, S., Jiang, H., Qiao, K., Gui, W., Zhu, G. (2019). Insights into the effect on silkworm (Bombyx mori) cocooning and its potential mechanisms following non-lethal dose tebuconazole exposure. Chemosphere 234, 338-345.

Malysheva, S. V., Shmatko, V. Y., Spiridonov, S. E. (2020). Revision of Severianoia (Schwenk, 1926) Travassos, 1929 (Nematoda: Oxyuridomorpha) with proposal of S. pachyiuli n. sp. from millipedes of the Western Caucasus. Nematology 1-15.

Matsumura, M., Sanada-Morimura, S., Otuka, A., Ohtsu, R., Sakumoto, S., Takeuchi, H., Satoh, M. (2013). Insecticide susceptibilities in populations of two rice planthoppers, Nilaparvata lugens and Sogatella furcifera, immigrating into Japan in the period 2005-2012. Pest Management Science 70(4), 615-622.

McKillup, Dr. S. C, Harten, A. Van., Neves, A. M. (1991). Assessment of a rhabditid nematode, Rhabditis necromena Sudhaus and Schulte, as a biological control agent against the millipede Spinotarsus caboverdus Pierrard in the Cape Verde Islands, West Africa. Journal of Applied Entomology 111(1-5), 506-513.

Michaud, J. P. (2001). Responses of two ladybeetles to eight fungicides used in Florida citrus: Implications for biological control. Journal of Insect Science 1, 6 .

Milenković, S. N., Marcic, D. (2012). Raspberry leaf and bud mite (Phyllocoptes gracilis) in Serbia: The pest status and control options. Acta Horticulturae 946, 253-256.

Morffe, J., Hasegawa, K. (2017). Rhigonema naylae n. sp. (Rhigonematomorpha: Rhigonematidae) a new parasitic nematode from a Japanese polydesmid millipede (Polydesmida: Xystodesmidae). Zootaxa 4269(2). 277-286.

Moroz, K. O., Brygadyrenko, V. V., Pakhomov, A. Y. (2011). Formirovanije fauny napochvennykh bespozvonochnykh peschanoj terrasy r. Orel'v uslovijakh pirogennoj sukcessii [Litter invertebrates fauna formation of the sandy terrace of Orel'river in condition of post-fire succession]. Proc. of the Azerbaijan Soc. of Zool 3, 423-435 (in Russian).

Mullin, C. A., Frazier, M., Frazier, J. L., Ashcraft, S., Simonds, R., Vanengelsdorp, D., Pettis, J. S. (2010). High levels of miticides and agrochemicals in North American apiaries: Implications for honey bee health. PloS One 5(3), e9754.

Nyman, A. M., Schirmer, K., Ashauer, R. (2012). Toxicokinetic-toxicodynamic modelling of survival of Gammarus pulex in multiple pulse exposures to propiconazole: model assumptions, calibration data requirements and predictive power. Ecotoxicology (London, England) 21(7), 1828-1840.

Pakhomov, A. Y., Kul'bachko, Y. L., Didur, O. O. (2008). Model' vzayemodiyi shtuchnykh hruntovykh sumishey rekul'tyvovanykh terytoriy i hruntovykh saprofahiv (Diplopoda) [Model of interaction of artificial soil mixtures reclaimed territories and soil saprophages (Diplopoda)]. Reports of the NAS of Ukraine 9, 150-155.

Pakhomov, A. Y., Kul'bachko, Y. L., Didur, O. A. (2008). Izmeneiye biomassy predstaviteley dvuparnonogikh mnogonozhek (Diplopoda) na iskusstvennykh pochvogruntakh v model'nykh eksperimentakh [Variability dynamics of millipedes (Diplopoda) biomass in artificial soil's in the model experiments]. Odesa National University Herald. Biology 13(4), 159-167.

Pakhomov, O. Y., Brygadyrenko, V. V. (2005). Koncepcija systemy zahodiv z ohorony navkolyshn'ogo pryrodnogo seredovyshha Dnipropetrovs' koi'oblasti na 2005-2015 roky [Concept of system for actions on environment protection in Dnipropetrovsk region for 2005-2015]. Visnyk of Dnipropetrovsk University. Biology, Ecology 13(1), 213-225 (in Ukrainian).

Pakhomov, O. Y., Kunakh, O. M., Babchenko, A. V., Fedushko, M. P., Demchuk, N. I., Bezuhla, L. S., \& Tkachenko, O. S. (2019). Temperature effect on the temporal dynamic of terrestrial invertebrates in technosols formed after reclamation at a post-mining site in Ukrainian steppe drylands. Biosystems Diversity 27(4), 322-328.

Pakhomov, O. Y., Pokhylenko, A. P., Faly, L. I., Hirna A. Y. (2008). Riznomanittya uhrupovan' nagruntovykh bezkhrebetnykh lisovykh ekosystem Prysamar"ya Dniprovs'koho [Diversity of groups of soil invertebrate forest ecosystems of Prysamary Dnieper]. Sci. Bull. Uzhgorod Univ. (Ser. Biol.) 24, 40-47 (in Ukrainian).

Phillips, G., Moulton, J., Bernard, E. (2020). Heth pivari n. sp. (Nematoda: Ransomnematoidea: Hethidae) from the indigenous North American millipede Narceus gordanus (Spirobolida: Spirobolidae), with keys for worldwide Heth spp. Zootaxa 4861(4), 486-514.

Piechowicz, B., Mróz, K., Szpyrka, E., Zwolak, A., Grodzicki, P. (2018). Transfer of plant protection products from raspberry crops of Laszka and Seedling varieties to beehives. Environmental Monitoring and Assessment 190(3), 135 .

Poinar, G., Thomas, G. M. (1985). Effect of neoaplectanid and heterorhabitid nematodes (Nematoda: Rhabditoidea) on the millipede Oxidus gracilis. Journal of Invertebrate Pathology 45(2), 231-235.

Pokhylenko, A. P., Didur, O. O., Kulbachko, Y. L., Fedorov P. R. (2019). Akumulyatsiya tsynku predstavnykamy saprofahiv (Diplopoda, Julidae, Rossiulus kessleri) v umovakh khimichnoho navantazhennya [Zinc accumulation by saprophagous (Diplopoda, Julidae, Rossiulus kessleri) in conditions of chemical loading]. Ecological Sciences 25(2), 177-181 (in Ukrainian)

Pokhylenko, A., Didur, O., Kulbachko, Y., Ovchynnykova, Y. (2019). Trophic selectivity of litter saprophages (Diplopoda, Isopoda) in natural forests in the steppe conditions. Ecology and Noospherology 30. 24-28.

Pokhylenko, A., Korolev, O., Shul'man, M. (2009). Osoblyvosti uhrupovan' pidstylkovykh bezkhrebetnykh tekhnohennotransformovanykh terytoriy na prykladi $\mathrm{m}$. Dnipropetrovs'ka [Peculiarities of litter invertebrate's complexes in man-caused transformed territories in outskirts of Dnipropetrovs'k city]. Problems of bioindications and ecology 14(1), 121-134 (in Ukrainian). 
Prokopenko, E. V., Zhukov, A. V. (2011). Raznoobraziye gerpetobiontnykh bespozvonochnykh na eksperimental'nom uchastke rekul'tivatsii zemel', narushennykh gornodobyvayushchey promyshlennost'yu [The diversity of the herpetobiont invertebrates community on the recultivation experimental site on the soil destroyed by the mining]. Problems of ecology and nature protection of technogenic region 1(11), 172-187 (in Russian).

Qi, S. Z., Chen, X. F., Liu, Y., Jiang, J. Z., Wang, C. J. (2015). Comparative toxicity of rac- and S-tebuconazole to Daphnia magna. Journal of environmental science and health. Part. B, Pesticides, food contaminants, and agricultural wastes 50(7), 456-462.

Rumbos, C. I., Dutton, A. C., Tsiropoulos, N. G., Athanassiou, C. G. (2018). Persistence and residual toxicity of two pirimiphosmethyl formulations on wheat against three stored-product pests. Journal of Stored Products Research 76, 14-21.

Schulte, F. (1989). The association between Rhabditis necromena Sudhaus \& Schulte, 1989 and native and introduced millipedes in South Australia. Nematologica 35(1), 82-89.

Shulman, M. V., Pakhomov, O. Y., Brygadyrenko, V. V. (2017). Effect of lead and cadmium ions upon the pupariation and morphological changes in Calliphora vicina (Diptera, Calliphoridae). Folia Oecologica,44(1), $\underline{28-37 .}$

Skourti, A., Kavallieratos, N. G., Papanikolaou, N. E. (2020). Exposure of Tribolium castaneum (Herbst) females to pirimiphos-methyl alters the fitness of their progeny. Environmental Science and Pollution Research, 28(7), 7893-7900.

Stanley, J., Sah, K., Jain, S. K., Bhatt, J. C., Sushil, S. N. (2015). Evaluation of pesticide toxicity at their field recommended doses to honeybees, Apis cerana and $A$. mellifera through laboratory, semi-field and field studies. Chemosphere 119, 668-674.

Svyrydchenko, A. O., Brygadyrenko, V. V. (2014). Trophic preferences of Rossiulus kessleri (Diplopoda, Julidae) for the litter of various tree species. Folia Oecologica, 41(2), 202-212.
Tillman, P. G. (1995). Susceptibility of Microplitis croceipes and Cardiochiles nigriceps (Hymenoptera: Braconidae) to field rates of selected cotton insecticides. Journal of Entomological Science 30(3), 390-396.

Tosi, S., Nieh, J. C. (2019). Lethal and sublethal synergistic effects of a new systemic pesticide, flupyradifurone $\left(\right.$ Sivanto $\left.^{\circledR}\right)$, on honeybees. Proceedings. Biological sciences 286(1900), 20190433.

Vandenberg, L. N., Blumberg, B., Antoniou, M. N., Benbrook, C. M., Carroll, L., Colborn, T., Everett, L. G., Hansen, M., Landrigan, P. J., Lanphear, B. P., Mesnage. R., vom Saal, F. S., Welshons, W. V., Myers, J. P. (2017). Is it time to reassess current safety standards for glyphosate-based herbicides? Journal of Epidemiology and Community Health 71(6). $613-618$

Yakuba, M. S., Pokhylenko, A. P., Brygadyrenko, V. V. (2003). Vplyv Rossiulus kessleri (Diplopoda) na rozkladannya pidstylky u bayrachnykh ekosystemakh Prysamar'ya Dniprovs'koho [Influence of Rossiulus kessleri (Diplopoda) on the litter decomposition in the natural ravine forest in steppe ecosystems of Prisamaria Dnieprovsky]. Problems of Bioindications and Ecology 8(1), 41-47 (in Ukrainian).

Zhukov, O. V., Gudym, N. G., Dubinina, Y. Y. (2017). Dynamika uhrupovannya herpetobiontiv u zaplavi r.Protich Pryrodnyy zapovidnyk "Dniprovs'ko-Oril's'kyy" [Dynamic of the herpetobiont community in the floodplain of the Protich River Dnyprovsko-Orylsky Nature Reserve]. The Kharkov Entomological Society Gazette 25(2), 22-39 (in Ukrainian).

Zhukov, O., Kunah, O., Baljuk, J. (2014). Prostorove variyuvannya ekomorfichnoyi struktury gruntovoyi mezofauny lisoparkovoho nasadzhennya (na prykladi parku v mezhakh $\mathrm{m}$. Dnipropetrovs'ka) [The spatial variation of soil mesofauna ecomorphic structure in artificial forest planting (in Dnipropetrovsk park as example)]. Visnyk of the Lviv University, Series Biology 65, 224-237 (in Ukrainian). 